\title{
Jurist-Diction
}

Volume 4 No. 2, Maret 2021

\section{Pertanggungjawaban Pidana Komunitas Penyebaran Berita Bermuatan Sara Melalui Media Sosial}

\author{
Aurellya Desita Ananda Putri \\ aurellyadesitaaa@gmail.com \\ Universitas Airlangga
}

How to cite:

Aurellya Desita Ananda

Putri`Pertanggungjawaban

Pidana Komunitas Penyebaran

Berita Bermuatan Sara Melalui

Media Sosial' (2021) Vol. 4

No. 2 Jurist-Diction.

Histori artikel:

Submit 15 Januari 2021;

Diterima 20 Februari 2021;

Diterbitkan 1 Maret 2021.

DOI:

10.20473/jd.v4i2.25752

p-ISSN: 2721-8392

e-ISSN: $2655-8297$

\section{Abstract}

In this millennial era, sharing and accessing information and news is very easy. This is because technology has increasingly developed among the people. People easily access information and news through social media. The government made a regulation related to the problem, namely the ITE Law. Along with the times, the provocative issue of spreading news containing SARA (Tribe, Religion, Race and Intergroup) also emerged in the use of social media because of the use of free and easy media. If the subject in question is a community as an example of a case for the spread of hate speech containing SARA Saracen. In this thesis will discuss the criminal liability of the SARA news disseminating community, using normative juridical legal research methods and accompanied by a statute approach and conceptual approach. The results of the research conducted by the author show that criminal liability in the community for distributing SARA-charged news is imposed by individuals rather than a community by adhering to the vicarious liability doctrine and that criminal sanctions are subject to article 28 paragraph (2) of the ITE Law.

Keywords: Hate Speech; Community; SARA; Social media.

\begin{abstract}
Abstrak
Pada era milenial ini, membagikan serta mengakses informasi dan berita sangatlah mudah. Hal ini karena teknologi yang sudah semakin berkembang di kalangan masyarakat. Masyarakat mudah mengakses informasi dan berita melalui media sosial. Pemerintah membuat regulasi terkait dengan masalah tersebut yaitu UU ITE. Seiring dengan perkembangan zaman, isu provokatif penyebaran berita bermuatan SARA (Suku, Agama, Ras dan Antargolongan) pun muncul dalam penggunaan media sosial karena penggunaan media yang bebas dan mudah. Apabila subjek yang dimaksud adalah komunitas sebagai contoh kasus sindikat penebar ujaran kebencian bermuatan SARA Saracen. Dalam skripsi ini akan membahas mengenai pertanggungjawaban pidana komunitas penyebaran berita bermuatan SARA, dengan menggunakan metode penelitian hukum yuridis normatif dan disertai pendekatan statute approach dan conceptual approach. Hasil dari penelitian yang dilakukan penulis menunjukkan bahwa pertanggungjawaban pidana komunitas penyebaran berita bermuatan SARA dikenakan perseorangan bukan sebuah komunitas nya dengan menganut doktrin vicarious liability dan sanksi pidana nya dikenakan pasal 28 ayat (2) UU ITE.

Kata Kunci: Ujaran Kebencian; Komunitas; SARA; Media Sosial.
\end{abstract}

Copyright $(\odot 2021$ Universitas Airlangga 


\section{Pendahuluan}

Indonesia merupakan salah satu negara kepulauan terbesar di dunia, yang terdiri atas 17.508 pulau besar dan kecil, dengan luas daratan 1,937 juta km2, dan luas lautan 5,8 juta $\mathrm{km} 2 .{ }^{1}$ Dengan populasi penduduk kurang lebih 270.054 .853 jiwa terhitung tahun 2018. Disamping itu, karena populasi penduduk Indonesia lebih dari 230 juta jiwa, maka secara tidak langsung memiliki beragam suku, budaya, agama, ras, serta bahasa yang terikat dengan semboyan Bhineka Tunggal Ika yang artinya berbeda-beda tetapi tetap satu jua. Keberagaman merupakan kekayaan bangsa namun tak dapat dipungkiri kekayaan ini berpotensi menimbulkan perpecahan. ${ }^{2}$

Sebagaimana diatur dalam Pasal 28 E Undang-Undang Dasar Negara Republik Indonesia 1945 yang berbunyi:

(1) Setiap orang berhak memeluk agama dan beribadat menurut agamanya, memilih pendidikan dan pengajaran, memilih pekerjaan, memilih kewarganegaraan, memilih tempat tinggal di wilayah negara dan meninggalkannya, serta berhak kembali.

(2) Setiap orang berhak atas kebebasan meyakini kepercayaan, menyatakan pikiran dan sikap, sesuai dengan hati nuraninya.

(3) Setiap orang berhak atas kebebasan berserikat, berkumpul dan mengeluarkan pendapat.

Pasal 28 E Undang-Undang Dasar Negara Republik Indonesia 1945 tersebutmerupakan aturan yang dibuat sebagai dasar pengaturan dari keberagaman suku, budaya, agama, ras, serta bahasa di masyarakat Indonesia. Sehingga mengurangi resiko adanya perpecahan antar-sesama masyarakat Indonesia. Isu yang sering timbul di masyarakat pada saat ini salah satunya adalah Isu provokatif penyebaran berita bermuatan SARA (Suku, Agama, Ras, dan Antargolongan).

Pada era milenial ini, membagikan serta mengakses informasi dan berita sangatlah mudah. Hal ini karena teknologi yang sudah semakin berkembang di kalangan masyarakat. Masyarakat mudah mengakses informasi dan berita melalui media sosial. Kata media sosial berasal dari kata "media" yang menurut Black Law

\footnotetext{
${ }^{1}$ Ridwan Lasabuda, 'Pembangunan Wilayah Pesisir dan Lautan dalam Prespektif Negara Kepulauan Republik Indonesia' (2013) 1-2 Jurnal Ilmiah Platax.[93].

2 Dania Shofi Maziyah, 'Batasan Pengaturan Forum Eksternum Dalam Pembentukan Peraturan Perundang-Undangan di Indonesia: Analisis Undang-Undang Nomor 33 Tahun 2014 tentang Jaminan Produk Halal' (Skripsi, Universitas Airlangga 2019).[1].
} 
Dictionary, news, entertainment, education, data, and promotional messages are sent world-wide trough this type of communication channels. ${ }^{3}$ Sehingga menurut bahasa artinya berita, hiburan, Pendidikan, data dan pesan yang dikirim ke seluruh dunia melalui saluran komunikasi.

Menurut McGraw Hill Dictionary, definisi dari media sosial adalah sarana yang digunakan oleh orang-orang untuk berinteraksi satu sama lain dengan cara menciptakan, berbagi, serta bertukar informasi dan gagasan dalam sebuah jaringan sosial. ${ }^{4}$ Jejaring sosial seperti Facebook, Twitter, Instagram, Whatsapp dan lainlain sebagai contoh model interaksi. Lalu, menurut Andreas Kaplan dan Michael Haenlein mengatakan bahwa media sosial sebagai sebuah kelompok aplikasi berbasis internet yang membangun di atas dasar ideologi dan teknologi Web 2.0, dan yang memungkinkan penciptaan dan pertukaran user-generated content. ${ }^{5}$ Jadi pada intinya media sosial adalah sebuah media dimana penggunanya bisa dengan bebas dan mudah untuk mengakses, berbagi, dan menciptakan pergaulan sosial-nya sendiri.

Dengan penggunaan internet yang sangat populer pada era ini, maka pemerintah membuat regulasi terkait kondisi tersebut. Pemerintah membuat aturan yaitu Undang-Undang Nomor 11 Tahun 2008 tentang Informasi dan Transaksi Elektronik (Lembaran Negara Republik Indonesia Tahun 2008 Nomor 58, Tambahan Lembaran Negara Republik Indonesia Nomor 4843, untuk selanjutnya disingkat UU ITE) jo. Undang-Undang Nomor 19 Tahun 2016 tentang Perubahan Atas Undang-Undang Nomor 11 Tahun 2008 tentang Informasi dan Transaksi Elektronik (Lembaran Negara Republik Indonesia Tahun 2016 Nomor 251, Tambahan Lembaran Negara Republik Indonesia No. 5952).

Seiring dengan perkembangan zaman, isu provokatif penyebaran berita bermuatan SARA (Suku, Agama, Ras dan Antargolongan) pun muncul dalam penggunaan media sosial karena penggunaan media yang bebas dan mudah. Terkait pengertian dari Isu

3 The Law Dictionary, <https://thelawdictionary.org/media > dikunjungi pada 12 Agustus 2019.

4 Ambar, '20 Pengertian Media Sosial Menurut Para Ahli' (Pakar Komunikasi 2017) <https:// pakarkomunikasi.com/pengertian-media-sosial-menurut-para-ahli> dikunjungi pada 11 Agustus 2019.

5 Michael Haenlein, 'Users of the world, unite! The challenges and oppurtunities of Social Media' (2010) Bussiness Horizons.[59]. 
sendiri merupakan titik awal munculnya konflik yang setelah itu akan berkembang menjadi masalah baru. Isu SARA yang timbul pada rentan waktu 2013-2015 terdapat berbagai bentuk yaitu Isu Suku, Isu Agama, Isu Ras, Isu Antargolongan.

Sehingga, dapat disimpulkan bahwa dengan adanya penyebaran berita bermuatan Isu SARA (Suku, Agama, Ras dan Antargolongan) melalui media sosial yang timbul pada masyarakat, maka dampak faktual yang akan terjadi menyebabkan perpecahan di kalangan masyarakat baik antar suku, agama, ras maupun antar golongan. UU ITE mengatur khusus mengenai SARA ini. Yaitu pada Pasal 28 ayat (2) UU Informasi dan Transaksi Elektronik, Setiap orang dengan sengaja dan tanpa hak menyebarkan informasi yang ditujukan untuk menimbulkan rasa kebencian atau permusuhan individu dan/atau kelompok masyarakat tertentu berdasarkan suku, agama, ras dan antargolongan (SARA).

Apabila terdapat kasus seperti berikut, yaitu terkuaknya kasus sindikat penebar ujaran kebencian bernama Saracen. Polisi membongkar sindikat penebar ujaran kebencian bernama Saracen ini pada pertengahan 2017 lalu. Dipimpin oleh Jasriadi, jaringan ini ternyata telah memproduksi dan menyebarkan konten kebencian bernada SARA sejak November 2015. Polisi mengungkapkan, Saracen sebagai salah satu jaringan terorganisir penebar kebencian melalui media sosial (media sosial). Di dunia maya, peran para sindikat penebar kebencian ini saling berkaitan. Grup-grup media sosial diibaratkan pasar. Para pembuat meme, narasi dan gambar di-posting di grup. Ada 800 ribu akun medsos yang berkaitan dengan grup Saracen. Akun-akun ini bersama-sama menyebar konten kebencian dan berita hoaks, walau pemilik akun tak saling mengenal. Bahkan, konten hinaan terhadap Presiden Jokowi yang diunggah Muhammad Farhan Balatif juga tersebar di "pasar" Saracen.

Subjek hukum yang dimaksud dalam kasus di atas adalah komunitas, maka bagaimana pengenaannya dalam UU ITE apabila terdapat kasus-kasus lain yang subjek hukum nya adalah sebuah komunitas, karena dalam Pasal 28 ayat (2) UU ITE hanya dikatakan subjek hukumnya "setiap orang” saja, sehingga ada ketidakjelasan pada pasal ini sehingga perlu dilakukan peng-kajian. 


\section{Tindak Pidana Ujaran Kebencian Bermuatan SARA Menurut KUHP}

Di masyarakat Indonesia, menghargai sesama merupakan tujuan dibentuknya hukum oleh pemerintah. Beberapa peraturan perundang-undangan pada hukum positif Indonesia baik didalam KUHP maupun di luar KUHP telah dibuat untuk menyelesaikan permasalahan tersebut. ${ }^{6}$ Mengingat, Indonesia memiliki beragam suku, agama, ras, serta antar golongan. Tindak pidana ujaran kebencian dianggap melanggar norma yang berlaku di masyarakat karena sangat erat kaitannya dengan fitnah dan penghinaan yang dilakukan dengan rasa benci sehingga dapat memecah belah keutuhan Negara Kesatuan Republik Indonesia (NKRI), maka dari itu harus dipidana dengan dibentuknya peraturan perundang-undangan. ${ }^{7}$

Dalam KUHP, tindak pidana ujaran kebencian bermuatan SARA dijelaskan pada Bab V buku II KUHP yang termasuk dalam kejahatan terhadap ketertiban umum. Tindak pidana ujaran kebencian bermuatan SARA dalam KUHP dirumuskan dalam beberapa pasal yaitu Ujaran kebencian di muka umum (Pasal 156 KUHP), Ujaran kebencian agama (Pasal 156 a), Menyiarkan ujaran kebencian (Pasal 157 KUHP). Ujaran kebencian bermuatan SARA adalah salah satu bentuk dari penghinaan. Kemudian, akan secara rinci dijelaskan tindak pidana ujaran kebencian dalam KUHP:

Ujaran kebencian di muka umum - Pasal 156 KUHP

Barang siapa di muka umum menyatakan perasaan permusuhan, kebencian atau penghinaan terhadap suatu atau beberapa golongan rakyat Indonesia, diancam dengan pidana penjara paling lama empat tahun atau pidana dendan paling banyak empat ribu lima ratus rupiah.

Ujaran kebencian agama - Pasal 156a KUHP

Dipidana dengan pidana penjara selama-lamanya lima tahun barang siapa dengan sengaja di muka umum mengeluarkan perasaan atau melakukan

6 Nella Sumika Putri dan Tim Lembaga Bantuan Hukum Bandung, Analisis Pasal 156 a KUHP dan UU No. 1 tahun 1965 terkait tindak pidana penodaan agama yang terjadi di Jawa Barat, (Opini Hukum 2000).[8].

7 Reda Manthovani, 'Meluruskan Istilah Kritik, Fitnah, dan Ujaran Kebencian Oleh: Reda Manthovani' (hukum online 2019) < https://www.hukumonline.com> dikunjungi pada tanggal 1 November 2019. 
perbuatan :

a. Yang pada pokoknya bersifat permusuhan, penyalahgunaan atau penodaan terhadap suatu agama yang dianut di Indonesia.

b. Dengan maksud agar supaya orang tidak menganut agama apa pun juga, yang bersendikan Ketuhanan Yang Maha Esa.

Menyiarkan ujaran kebencian - Pasal 157 KUHP

(1) Barang siapa menyiarkan, mempertunjukkan atau menempelkan tulisan atau lukisan di muka umum, yang isinya mengandung pernyataan perasaan permusuhan, kebencian atau penghinaan di antara atau terhadap golongangolongan rakyat Indonesia, dengan maksud supaya isinya diketahui atau lebih diketahui oleh umum, diancam dengan pidana penjara paling lama dua tahun enam bulan atau pidana denda paling banyak empat ribu luma ratus rupiah.

(2) Jika yang bersalah melakukan kejahatan tersebut pada waktu menjalankan pencariannya dan pada saat itu belum lewat lima tahun sejak pemidanaannya menjadi tetap karena kejahatan semacam itu juga, yang bersangkutan dapat dilarang menjalankan pencarian tersebut.

Perkataan golongan dalam pasal-pasal diatas mempunyai arti bahwa tiaptiap bagian dari rakyat Indonesia yang berbeda dengan suatu atau beberapa bagian lainnya karena ras, negeri asal, agama, tempat asal, keturunan, kebangsaan, atau kedudukan menurut hukum tata negara. Pada dasarnya, setiap perbuatan pidana harus terdiri dari unsur-unsur lahiriah (fakta) oleh perbuatan serta mengandung kelakuan dan akibat yang ditimbulkan karenanya. Keduanya merupakan faktor munculnya kejadian tindak pidana. ${ }^{8}$

Tindak Pidana Ujaran Kebencian menurut Undang-Undang No. 11 Tahun 2008 jo. Undang-Undang No. 19 Tahun 2016 tentang Informasi dan Transaksi Elektronik (UU ITE)

Pada era milenial ini, masyarakat Indonesia sangat mudah mengakses media sosial sehingga pemerintah membuat regulasi yaitu UU ITE dengan tujuan tercantum dalam pasal 3 dan 4 UU ITE.

Pasal 3

Pemanfaatan Teknologi Informasi dan Transaksi Elektronik dilaksanakan berdasarkan asas kepastian hukum, manfaat, kehati-hatian, iktikad baik, dan

8 Moeljanto, Asas-Asas Hukum Pidana (Penerbit Rineka Cipta 2015).[64]. 
kebebasan memilih teknologi atau netral teknologi.

\section{Pasal 4}

Pemanfaatan Teknologi Informasi dan Transaksi Elektronik dilaksanakan dengan tujuan untuk:

a. Mencerdaskan kehidupan bangsa sebagai bagian dari masyarakat informasi dunia;

b. Mengembangkan perdagangan dan perekonomian nasional dalam rangka meningkatkan kesejahteraan masyarakat;

c. Meningkatkan efektivitas dan efisiensi pelayanan publik;

d. Membuka kesempatan seluas-luasnya kepada setiap Orang untuk memajukan pemikiran dan kemampuan di bidang penggunaan dan pemanfaatan Teknologi Informasi seoptimal mungkin dan bertanggung jawab; dan

e. Memberikan rasa aman, keadilan, dan kepastian hukum bagi pengguna dan penyelenggara Teknologi Informasi

Sehingga tujuan pemerintah sangat jelas sesuai dengan Pancasila sebagai ideologi bangsa yaitu sila ke-2, "Kemanusiaan yang adil dan beradab" yang mempunyai arti sesama masyarakat Indonesia harus saling menghargai, mencintai, tidak semena-mena serta mengembangkan sikap tenggang rasa agar tidak dengan seenaknya menyebarkan ujaran kebencian dalam hal suku, agama, ras dan antar golongan yang dapat memecah belah bangsa Indonesia. Tidak dapat dipungkiri bahwa Teknologi Informasi adalah pedang bermata dua, disamping memberikan kontribusi bagi peningkatan kesejahteraan, kemajuan dan peradaban manusia, sekaligus menjadi sarana efektif perbuatan melawan hukum. ${ }^{9}$

Tindak pidana ujaran kebencian bermuatan SARA dalam UU ITE diatur secara khusus dalam Pasal 28 (2), yang berbunyi:"Setiap Orang dengan sengaja dan tanpa hak menyebarkan informasi yang ditujukan untuk menimbulkan rasa kebencian atau permusuhan individu dan/atau kelompok masyarakat tertentu berdasarkan atas suku, agama, ras, dan antargolongan (SARA)".

Berdasarkan pasal-pasal dalam UU ITE seperti diatas tindak pidana dalam UU ITE tergolong dalam tindak pidana biasa bukan tindak pidana aduan. Maksutnya adalah meskipun tidak ada laporan dari masyarakat, jika ada dugaan atau sangkaan

9 Didik Endro P, Hukum Pidana Untaian Pemikiran (Pusat Penerbitan dan Percetakan Universitas Airlangga (AUP) 2019).[55]. 
sedang, akan dan sudah terjadi tindak pidana di bidang ITE, maka aparat penyelidik dan penyidik dapat langsung melakukan pemrosesan tidak perlu menunggu adanya laporan dari masyarakat yang bersangkutan. ${ }^{10}$

Menurut pasal 28 (2) UU ITE orang/badan hukum yang melakukan tindak pidana ujaran kebencian bermuatan SARA dapat dikenakan pasal tersebut apabila memenuhi unsur-unsur sebagai berikut: (1) Setiap orang; (2) Dengan sengaja dan tanpa hak; (3) menyebarkan informasi (4) untuk menimbulkan rasa kebencian atau permusuhan individu dan/atau kelompok masyarakat tertentu.

Tindak Pidana Ujaran Kebencian menurut Undang-Undang No. 40 Tahun 2008 tentang Penghapusan Diskriminasi Ras dan Etnis

Pada era milenial ini, terkait maraknya penyebaran ujaran kebencian bermuatan SARA seperti yang terjadi di Surabaya yaitu diskriminasi rasial mahasiswa Papua. ${ }^{11}$ Pemerintah membuat regulasi khusus untuk diskriminasi ras dan etnis yaitu UU PDRE. Tujuan dibentuknya UU PDRE oleh pemerintah diatur dalam Pasal 3. Dalam UU PDRE tidak dijelaskan secara spesifik tentang SARA itu sendiri seperti pada UU ITE sebelumnya, hanya mengatur secara khusus aturan mengenai penghapusan diskriminasi ras dan etnis.

Menurut pasal 4 UU PDRE yang melakukan tindak pidana ujaran kebencian bermuatan SARA dapat dikenakan pasal tersebut apabila memenuhi unsur-unsur sebagai berikut: (1) melakukan pembedaan, pengecualian, pembatasan, atau pemilihan; (2) berdasarkan ras dan etnis; (3) yang mengakibatkan pencabutan atau pengurangan pengakuan atau menunjukkan kebencian atau rasa benci kepada orang.

Dapat ditarik kesimpulan bahwa tindak pidana ujaran kebencian dalam peraturan perundang-undangan ada berbagai macam bentuknya. Tetapi, apabila dikaitkan dengan judul skripsi diatas maka yang paling memenuhi adalah

\footnotetext{
${ }^{10}$ ibid.[61].

${ }^{11}$ Ady Thea DA, 'Dugaan Diskriminasi Rasial Mahasiswa Papua Harus Diselesaikan Secara Hukum' (Hukum Online 2019) < https:/www.hukumonline.com> dikunjungi pada tanggal 3 November 2019.
} 
menggunakan UU ITE. Sebab, UU ITE lebih diutamakan daripada KUHP karena adanya asas Lex Specialis Derogat Legi Generalis. Kemudian, jika dibandingkan dengan UU PDRE, UU PDRE tidak mengatur secara khusus media yang digunakan adalah media sosial. Sedangkan, apabila UU ITE mengatur khusus dan jelas media yang digunakan adalah media social

\section{Komunitas Sebagai Subjek Hukum Pidana}

Berbicara mengenai korporasi, erat kaitannya dengan hukum positif di Indonesia. Secara etimologi korporasi mempunyai istilah lain yaitu corporatie dari Belanda, corporation dari Inggris, corporation dari Jerman. Korporasi berasal dari kata "corporatio" dalam bahasa Latin. Sama halnya dengan kata benda (substantivum), berasal dari kata corporare, yang banyak dipakai orang pada zaman Abad Pertengahan atau sesudah itu. Corporare sendiri berasal dari kata "corpus" (Indonesia=badan), yang memiliki arti badan atau membadankan. Dengan demikian, Corporatio yakni hasil dari pekerjaan membadankan, dengan kata lain badan yang dijadikan orang, badan yang diperoleh dengan perbuatan manusia sebagai lawan terhadap badan manusia, yang terjadi menurut alam. ${ }^{12}$ Sehingga berdasarkan uraian tersebut, korporasi adalah suatu badan hasil cipta hukum,

Korporasi sebagai subjek hukum dalam hukum pidana memiliki ruang lingkup yang lebih luas disbanding korporasi sebagai subjek hukum perdata. Pengertian korporasi dalam hukum pidana ialah sebagai ius constituendum yaitu hukum yang dicita-citakan oleh negara di masa yang akan datang. Sehingga, belum ada aturan atau undang-undang yang mengatur dengan jelas tentang korporasi. Hal ini dapat dijumpai dalam Konsep Rancangan KUHP Buku I Pasal 182 yakni, “Korporasi adalah kumpulan terorganisasi dari orang dan/atau kekayaan baik merupakan badan hukum maupun bukan badan hukum”.

Jika menengok ke belakang tentang pengertian korporasi dalam perundangundangan khusus di luar KUHP, yaitu dalam Pasal 15 UU No. 7/Drt/Tahun 1955

12 Muladi dan Dwidja Priyatno, Pertanggungjawaban Pidana Korporasi (Prenadamedia Group 2015).[23]. 
tentang Tindak Pidana Ekonomi, dinyatakan bahwa:

"Ayat(1): Jika suatu tindak pidana ekonomi dilakukan oleh atau atas nama suatu badan hukum, suatu perseroan, suatu perserikatan orang atau yayasan, maka tuntutan pidana dilakukan dan hukuman pidana serta tindakan tata-tertib dijatuhkan, baik terhadap mereka yang memberi perintah melakukan tindakpidana ekonomi itu atau yang bertindak sebagai pemimpin dalam perbuatan atau kelalaian itu, maupun terhadap kedua-duanya". ${ }^{13}$

Korporasi sebagai subjek hukum dapat berbentuk badan hukum dan non badan hukum. Korporasi yang berbentuk badan hukum bisa bermacam-macam yaitu a) PT (Perseroan Terbatas), b) yayasan dan c) koperasi. Badan Hukum adalah badan yang disamping manusia perorangan juga dianggap dapat bertindak dalam Hukum dan mempunyai hak-hak, kewajiban-kewajiban dan kepentingan hukum terhadap orang lain atau badan lain. Khususnya adalah adanya kekayaan terpisah dari kekayaan perseorangan dan yang harus dianggap dimiliki oleh sebuah badan diluar perseorangan. ${ }^{14}$ Sedangkan dalam korporasi yang berbentuk non badan hukum yaitu a) $\mathrm{CV} /$ Firma, b) maatschap atau persekutuan perdata, c) perkumpulan/komunitas dan d) ormas (organisasi kemasyarakatan).

Pengertian "Perkumpulan/Komunitas" sendiri adalah orang-orang perseorangan atau orang-orang yang mempunyai kepentingan, yang hanya atau lebih mungkin dapat diperhatikan secara memuaskan, apabila mereka berkumpul dan bekerja sama satu sama lain. ${ }^{15}$ Dengan kata lain sekumpulan orang yang memiliki minat dan kepentingan yang sama sehingga berkumpul. Untuk anggota yang berkumpul tergantung dari sebuah perkumpulan tersebut, bisa banyak sekali atau sedikit sekali. Bahkan apabila anggota hanya terdiri 2 orang saja sudah dapat dikatakan sebagai sebuah perkumpulan.

Tujuan dari dibentuknya sebuah perkumpulan tergantung dengan apa yang merupakan sifat dan keadaan bersama yang khusus diketemukan diantara para peserta perkumpulan. Sehingga tujuannya bisa tujuan yang jahat atau tujuan

\footnotetext{
13 ibid.[33].

${ }^{14}$ Wirjono Projodikoro, Hukum Perkumpulan Perseroan dan Koperasi di Indonesia (Penerbit Dian Rakyat 1978).[8].

15 Wirjono Projodikoro, Op.Cit.[1].
} 
yang positif. Dalam perkumpulan, tidak ada peraturan perundang-undangan yang mengatur jadi hanya terbentuk karena memiliki tujuan dan kepentingan sama yang ingin dicapai bersama-sama.

Jika persamaaan sifat dalam keadaan bersama dari sebuah perkumpulan atau komunitas ini adalah dengan tujuan untuk bersama-sama mengejar sebuah keahlian seperti hal nya para ahli-ahli, sarjana atau bahkan perkumpulan para atlit olahraga maka tujuan mereka tidaklah mencari keuntungan melainkan untuk kesejahteraan bangsa dan negara. Sehingga perkumpulan dalam arti sempit dapat disebut dengan "Perhimpunan" atau "Ikatan" atau "Persatuan".

Selain perkumpulan, akan dijelaskan lebih lanjut mengenai “Ormas”. Ormas (Organisasi Masyarakat) diatur oleh pemerintah dalam Undang-Undang Nomor 17 Tahun 2013 Tentang Organisasi Kemasyarakatan (Lembaran Negara Republik Indonesia Tahun 2013 Nomor 116, Tambahan Lembaran Negara Republik Indonesia Nomor 5430, untuk selanjutnya disingkat UU Ormas). Pengertian Ormas tercantum pada Pasal 1 angka 1 UU Ormas.

Pasal 1

Ormas adalah organisasi yang didirikan dan dibentuk oleh masyarakat secara sukarela berdasarkan kesamaan aspirasi, kehendak, kebutuhan, kepentingan, kegiatan, dan tujuan untuk berpartisipasi dalam pembangunan demi tercapainya tujuan Negara Republik Indonesia yang berdasarkan Pancasila.

Ormas bisa berbentuk badan hukum maupun non badan hukum. Perbedaan antara ormas yang berbentuk badan hukum dan non badan hukum adalah terdapat pada unsur materiil di dalam sebuah ormas yaitu cara pendaftarannya dan persyaratan sebuah ormas itu sendiri sebagaimana tercantum dalam Pasal 12 dan 16 UU Ormas

Dapat disimpulkan bahwa subjek Perkumpulan/Komunitas dapat disebut juga sebagai Ormas non badan hukum sebab memiliki karakteristik dan unsurunsur yang hampir sama. Dalam hal tujuan dari perkumpulan dan ormas itu sendiri terbentuk karena mempunyai kepentingan dan tujuan yang sama sehingga membentuk sebuah perkumpulan atau komunitas atau ormas sebagaimana diatur dalam Pasal 1 angka 1 definisi ormas. Kemudian, Selain itu dalam UU 
Ormas disebutkan dalam Pasal 59 ayat (2) bahwa dilarang melakukan tindakan permusuhan terhadap suku, agama, ras dan antar golongan (SARA) sehingga sesuai dengan apa yang dibahas dalam topik ini.

\section{Pertanggungjawaban Komunitas Menurut Prespektif Hukum Pidana}

Menurut korporasi terdapat 3 model pertanggungjawaban pidana, yaitu:

a. Pengurus korporasi sebagai pembuat dan penguruslah yang bertanggung jawab;

b. Korporasi sebagai pembuat dan pengurus bertanggung jawab;

c. Korporasi sebagai pembuat dan juga sebagai yang bertanggung jawab. ${ }^{16}$

Dalam hal pengurus korporasi sebagai pembuat dan penguruslah yang bertanggung jawab. Hal itu sangat bertolak belakang dengan dasar pemikiran bahwa badan hukum tidak dapat dipertanggungjawabkan secara pidana, karena penguruslah yang akan selalu dianggap pelaku dalam delik tersebut. Kemudian korporasi sebagai pembuat dan pengurus bertanggung jawab. Maksutnya adalah korporasi mungkin sebagai pembuat, tetapi pertanggungjawaban diserahkan kepada pengurus. Tindak pidana yang dilakukan korporasi adalah tindak pidana yang dilakukan orang tertentu sebagai pengurus dari badan hukum tersebut. Orang yang memimpin korporasi yang harus bertanggung jawab, terlepas pemimpin tersebut mengetahui perbuat tersebut atau tidak. Lalu, korporasi sebagai pembuat dan juga sebagai yang bertanggung jawab. Model ini memperhatikan bahwa perkembangan korporasi itu sendiri, karena ternyata hanya dengan menetapkan pengurus sebagai yang dapat dipidana tidaklah cukup, karena korporasi terkadang sebagai pihak yang diuntungkan dengan dilakukannya tindak pidana, sehingga pemidanaan terhadap pengurus tidak dapat menjamin bahwa korporasi tidak akan melakukan tindak pidana itu lagi.

Secara teoritis, menurut Sutan Remi Sjahdaeni teori-teori pertanggungjawaban pidana korporasi ada berbagai macam yaitu sebagai berikut: ${ }^{17}$

1. Doctrine of Strict Liability

Dapat dikatakan bahwa pertanggungjawaban pidana dapat dibebankan kepada

\footnotetext{
${ }^{16}$ Muladi dan Dwija Priyatno, Op.Cit.[86].

17 Sutan Remi Sjahdaeni, Pertanggung Jawaban Pidana Korporasi (Grafiti Pers 2007).[78-117].
} 
pelaku tindak pidana yang bersangkutan secara langsung (pertanggungjawaban mutlak) tidak perlu dibuktikan adanya unsur kesalahan (mens rea). Sehingga "strict liability" juga dapat dikatakan sebagai "liability without fault" (pertanggungjawaban pidana tanpa kesalahan). ${ }^{18}$

Menurut hukum positif di Indonesia biasanya strict liability berlaku terhadap 3 macam delik yaitu: ${ }^{19}$

a. Public nuisance (gangguan terhadap ketertiban umum, menghalangi jalan raya, mengeluarkan bau tidak enak).

b. Criminal libel (fitnah, pencemaran nama).

c. Contempt of court (pelanggaran tata tertib pengadilan).

2. Doctrine of Vicarious Liability

Vicarious liability adalah sebuah pertanggungjawaban pidana yang dibebankan kepada seseorang atas perbuatan orang lain (the legal of responsibility of one person for the wrongful acts of another). ${ }^{20}$ Terkait korporasi, korporasi harus bertanggung jawab atas perbuatan-perbuatan yang dilakukan oleh para pegawainya, kuasanya atau mandatarisnya, atau siapa pun yang bertanggung jawab kepada korporasi tersebut. Doktrin ini dapat juga diterapkan bagi hubungan majikan dan buruh.

3. Doctrine of Delegation

Berdasarkan doktrin ini, dasar pembenar untuk mempidanakan korporasi karena kesalahan pegawainya adalah karena adanya pendelegasian wewenang dari pemimpin ke pegawai sehingga pertanggungjawaban pidana ditujukan ke korporasi.

4. Doctrine of Identification

Doktrin ini mengajarkan bahwa untuk dapat membebankan pertanggungjawaban pidana kepada korporasi, siapa sebenarnya yang melakukan tindak pidana tersebut harus dapat diidentifikasi terlebih dahulu oleh penuntut umum. Apabila tindak pidana itu dilakukan oleh maraca yang merupakan "directing mind" dari korporasi tersebut, maka pertanggungjawaban tindak pidana itu baru dapat dibebankan kepada korporasi.

5. Doctrine of Aggregation

Doktrin ini menyatakan bahwa pertanggungjawaban pidana dapat dibebankan kepada badan hukum/korporasi jika perbuatan tersebut dilakukan oleh sejumlah orang yang memenuhi unsur delik yang mana antara satu dengan yang lain saling terkait dan bukan berdiri sendiri-sendiri.

Berdasarkan uraian di atas, apabila dibandingkan antara doktrin strict liability dan doktrin vicarious liability maka dapat ditemukan persamaan dan perbedaannya. Persamaan antara kedua doktrin ini yaitu sama-sama tidak mengindahkan adanya

\footnotetext{
${ }^{18}$ Barda Nawawi Arief, Pelengkap Bahan Kuliah Hukum Pidana I (FH Undip 1984).[68].

${ }_{19}$ Muladi dan Dwija Priyatno, Op. Cit.[112].

${ }^{20}$ Romli Atmasasmita, Asas-asas Perbandingan Hukum Pidana (Yayasan Lembaga Bantuan Hukum Indonesia 1989).[93].
} 
mens rea (kesalahan) atau tidak mensyaratkan adanya unsur kesalahan terhadap seorang yang akan dipidana. Sedangkan, perbedaan antara kedua doktrin ini, apabila strict liability pertanggungjawaban pidana nya bersifat mutlak atau langsung tidak perlu adanya pembuktian mens rea (kesalahan). Jika doktrin vicarious liability pertanggungjawaban pidana bersifat tidak langsung.

Apabila dikaitkan dengan subjek perkumpulan/komunitas terkait melakukan tindak pidana penyebaran ujaran kebencian bermuatan SARA yang mengganggu ketertiban umum serta masuk dalam delik penghinaan. Maka, doktrin yang cocok dalam pengenaan pertanggungjawaban pidana pada subjek hukum perkumpulan/ komunitas adalah doktrin vicarious liability. Karena dalam doktrin strict liability dalam pertanggungjawaban pidana bersifat mutlak atau langsung sehingga yang dapat diminta pertanggungjawaban adalah langsung sebuah korporasi nya. Sedangkan, doktrin vicarious liability pertanggungjawabannya tidak langsung sehingga harus ada pembuktian dan pengenaan pidana nya perseorangan. Dalam kasus ini, vicarious liability sangat cocok dengan pelaku penebar ujaran kebencian bermuatan SARA yang memerlukan adanya pembuktian terlebih dahulu. Sehingga, pelaku dapat dipidana karena dipenuhi nya unsur-unsur tindak pidana oleh perbuatannya. Jadi pengenaan pertanggungjawaban pidana terhadap pelaku penebar ujaran kebencian bermuatan SARA bersifat pertanggungjawaban tidak langsung.

\section{Kesimpulan}

Dalam subjek hukum komunitas pengenaan pertanggungjawaban pidana nya perseorangan sehingga tidak dikenakan komunitasnya seperti pada kasus diatas. Sehingga perbuatan materiil nya dapat dikenakan Pasal 28 ayat (2) UU ITE karena melakukan penyebaran ujaran kebencian bermuatan SARA, sedangkan untuk menentukan apakah komunitas sebuah subjek hukum pidana dapat dibuktikan dengan melihat UU Ormas non badan hukum karena karakteristiknya sama dengan sebuah perkumpulan atau komunitas.

Di Indonesia sendiri dalam hukum positif negara kita belum ada UU yang mengatur secara spesifik mengenai komunitas/perkumpulan (memenuhi delik apa). 
Sehingga pertanggungjawaban pidana nya menggunakan UU ITE karena masuk ke dalam subjek UU ITE Pasal 1 angka 22, yang berbunyi: "Badan Usaha adalah perusahaan perseorangan atau perusahaan persekutuan, baik yang berbadan hukum maupun yang tidak berbadan hukum". Sehingga dapat dibuktikan bahwa Komunitas merupakan badan usaha yang tidak berbadan hukum.

\section{Daftar Bacaan}

\section{Buku}

Barda Nawawi Arief, Pelengkap Bahan Kuliah Hukum Pidana I, (FH Undip 1984).

Didik Endro P, Hukum Pidana Untaian Pemikiran (Pusat Penerbitan dan Percetakan Universitas Airlangga (AUP) 2019).

Moeljanto, Asas-Asas Hukum Pidana (Penerbit Rineka Cipta 2015).

Muladi dan Dwidja Priyatno, Pertanggungjawaban Pidana Korporasi (Prenadamedia Group 2015).

Nella Sumika Putri dan Tim Lembaga Bantuan Hukum Bandung, Analisis Pasal 156 a KUHP dan UU No. 1 tahun 1965 terkait tindak pidana penodaan agama yang terjadi di Jawa Barat, (Opini Hukum 2000).

Romli Atmasasmita, Asas-asas Perbandingan Hukum Pidana (Yayasan Lembaga Bantuan Hukum Indonesia 1989).

Sutan Remi Sjahdaeni, Pertanggung Jawaban Pidana Korporasi (Grafiti Pers 2007).

Wirjono Projodikoro, Hukum Perkumpulan Perseroan dan Koperasi di Indonesia (Penerbit Dian Rakyat 1978).

\section{Jurnal}

Dania Shofi Maziyah, 'Batasan Pengaturan Forum Eksternum Dalam Pembentukan Peraturan Perundang-Undangan di Indonesia: Analisis Undang-Undang Nomor 33 Tahun 2014 tentang Jaminan Produk Halal' (Skripsi, Universitas Airlangga, 2019).

Michael Haenlein, 'Users of the world, unite! The challenges and oppurtunities of Social Media'(2010) Bussiness Horizons. 
Ridwan Lasabuda, 'Pembangunan Wilayah Pesisir dan Lautan dalam Prespektif Negara Kepulauan Republik Indonesia '(2013) 1-2 Jurnal Ilmiah Platax.

\section{Laman}

Ady Thea DA, 'Dugaan Diskriminasi Rasial Mahasiswa Papua Harus Diselesaikan Secara Hukum' (Hukum Online 2019) < https://www.hukumonline.com> dikunjungi pada tanggal 3 November 2019.

Ambar, '20 Pengertian Media Sosial Menurut Para Ahli' (Pakar Komunikasi 2017) $<$ https://pakarkomunikasi.com/pengertian-media-sosial-menurut-para-ahli> dikunjungi pada 11 Agustus 2019.

Reda Manthovani, 'Meluruskan Istilah Kritik, Fitnah, dan Ujaran Kebencian Oleh: Reda Manthovani' (hukum online 2019) <https://www.hukumonline. com> dikunjungi pada tanggal 1 November 2019.

The Law Dictionary, $<$ https://thelawdictionary.org/media $>$ dikunjungi pada 12 Agustus 2019. 